\title{
Cyber Dakwah: Plus Minus Penyiaran Islam Pada Era Disruptif
}

\author{
Dita Verolyna \\ Institut Agama Islam Negeri Curup \\ ditaverolyna@iaincurup.ac.id \\ Intan Kurnia Syaputri \\ Institut Agama Islam Negeri Curup \\ intankurnia@iaincurup.ac.id
}

\begin{abstract}
Da'wah aims to change behavior for the better and manifested in righteous deeds. $D a^{\prime} w a h$ becomes part of the communication process but not all communication means the process of da'wah. The use of online media becomes a challenge and opportunity for da'wah activities. At least the advantage of internet media is the increasing number of users. Therefore virtual da'wah or cyber da'wah becomes an inevitability nowadays. The research method in this paper uses virtual ethnography by observing the official media accounts of popular da'i in Indonesia, namely Khalid Basalamah, Abdul Somad and Hanan Attaki. The results of the researchers' observations are still based on islamic shirk and have not been eroded by the content commodification gap. Da'i utilizes technology to reach out to the wider mad'u and adapt to relevant media in the disruptive era.
\end{abstract}

Keywords: Da'wah, Cyber, Broadcasting, Disruptive

\begin{abstract}
Abstrak
Dakwah bertujuan untuk mengubah tingkah laku menjadi lebih baik dan diwujudkan dalam perbuatan amal sholeh. Dakwah menjadi bagian dari proses komunikasi tapi tidak semua komunikasi perarti proses dakwah. Pemanfaatan media online menjadi tantangan dan peluang bagi aktivitas dakwah.Setidaknya kelebihan media internet adalah jumlah pengguna yang semakin meningkat.Untuk itu dakwah virtual atau cyber dakwah menjadi suatu keniscayaan saat ini.Metode penelitian dalam tulisan ini menggunakan etnografi virtual dengan mengobservasi pada akun media resmi para da'i populer di Indonesia yaitu Khalid Basalamah, Abdul Somad dan Hanan Attaki. Hasil pengamatan peneliti saat ini para da'i kondang masih berpijak pada syiar islam dan belum tergerus oleh celah komodifikasi konten. Da’i memanfaatkan teknologi untuk menjangkau mad'u yang lebih luas dan beradaptasi dengan media yang relevan pada era disruptif.
\end{abstract}

Kata kunci : Dakwah, Siber, Penyiaran, Disruptif

Jurnal Dakwah dan Komunikasi

IAIN Curup-Bengkulu |E-ISSN: 2548-3366; P-ISSN: 2548-3293 


\section{Pendahuluan}

Komunitas dunia maya yang semakin meningkat ini menantang adanya model baru dalam cara berdakwah. Jarak akan digantikan ruang virtual dalam global village. Dunia maya memungkinkan keterbukaan dalam memperoleh informasi untuk meningkatkan kulaitas hidup.Peluang kejayaan dakwah dapat ditunjang dengan adanya perangkat teknologi yang mengumpulkan masyarakat majemuk.Cyberspace, begitu ruang virtual dikenal menandakan bahwa peradaban dunia semakin maju dan tingginya ilmu pengetahuan.

Relasi sosial yang terjalin diantara masyarakat maya memiliki kontak sosial dan hubungan komunikasi.Semakin canggihnya pemasaran dakwah dapat masuk dalam semua lini maupun saluran komunikasi.Saat ini situs dakwah di era disruptif semakin bervariasi. Fenomena munculnya situs islam dan dakwah digital menuntut dai dapat memnuhi kebutuhan informatif dari pada khalayak. Setidaknya ada bebarapa motivasi orang menggunakan internet dalam hidupnya menurut Ayusi dalam Iman ${ }^{1}$ seperti kebutuhan informasi, estetika, harga diri, afiliasi dan pelarian diri .

Teknologi membawa perubahan pada peradaban manusia.Berkaca pada keterbukaan arus informasi seperti sekarang, teknologi mempunyai peran yang sangat penting. Kegiatan yang dulunya dilakukan secara tradisional dan konvensional kini beralih ke cara digital. Perkembangan media juga berangsung beralih kepada media cyber (maya). Komunikasi interaktif dan komunikasi massa merupakan bagian dari internet atau media online ${ }^{2}$

Media mengalami perkembangan dalam beberapa tahap.Sejak zaman prasejarah hingga zaman ini tercatat beberapa fase pemutakhiran media. Era sekarang dikenal dengan era disruptif dimana media baru menjadi penghubung dan jawaban ketika jarak dan waktu menjadi kendala saat melakukan penyiaran islam secara massif. Keunggulan media online sendiri lebih cepat menjangkau khaayak luas dalam waktu real time.Namun hakikatnya media memiiliki peran dan fungsi masing-masing. Peran inilah yang tidak bisa menggantikan satu sama lain. Seperti surat kabar tidak digankan oleh rasio, maupun buku tidak bisa digantikan surat kabar. Semuanya memiliki keunikan sendiri ${ }^{3}$.

Saat ini banyak sekali bentuk konten dalam dunia digital. Penyebaran informasi mengenai kecantikan, gaya hidup, olahraga, kuliner dan lainnya beredar luas dengan berbagai macam kompetensi komunikator. Begitu juga penyiaran islam melalui dakwah, para da'i menempuh jalur maya untuk memperkuat jaringan khalayak dalam menyebarkan syiar islam.

Ruang siber juga memunculkan isu agama tentang dakwah. Dakwah berperan penting dalam penyebaran agama islam. Jelas untuk menjangkau belahan dunia tidak mungkin menggunakan metode ceramah cara lama. Padahal hal ini dibutuhkan untuk penjelasan tentang rahmatan lil alamin dalam konsep islam.

\footnotetext{
${ }^{1}$ M Sofiatul Iman, 'Praktisi Dakwah (Resolusi Da'i Dalam Menyikapi Masyarakat Cyber), Media Kita, 2.Juli 2018 (2018), 81-98.

${ }^{2}$ Andi Faisal Bakti, 'Trendsetter Komunikasi Di Era Digital: Tantangan Dan Peluang Pendidikan Komunikasi Dan Penyiaran Islam', 04 (2014).
}

${ }^{3}$ Bakti. 
Terlebih untuk masa pandemi, cyberspace menjadi tujuan utama dalam aktivitas komunikasi dan penyebaran informasi. Pemahaman yang baik tentang islam secara tepat tidak akan membuat islam menjadi agama dengan stigma negatif. Dakwah yang proporsional akan menempatkan islam sebagai agama yang diterima seluruh dunia. Dengan begitu tidak ada lagi istilah islamophobia ${ }^{4}$.

Dakwah merupakan bagian dari proses komunikasi yang melibatkan banyak unsur seperti komunkator, pesan, media, komunikan dan umpan baliknya. Yang membedakan dakwah dengan komunikasi non-islam adalah pada desain pesannya. Kegiatan syiar islam telah sejak dahulu kala dilakukan. Sebelumnya para alim ulama melakukan dnegan metode ceramah tatap muka di masjid atau majelis taklim. Namun saat ini dakwah telah mengalami perbahan cara sesuai dengan perkembangan zaman.

Hakikatnya dakwah mengharapkan perubahan tingkah laku menjadi lebih baik dan diwujudkan dalam perbuatan amal sholeh.Dakwah menjadi bagian dari proses komunikasi tapi tidak semua komunikasi perarti proses dakwah. Pemanfaatan media online menjadi tantangan dan peluang bagi aktivitas dakwah.Setidaknya kelebihan media internet adalah jumlah pengguna yang semakinmeningkat.Dengan peningkatan itu diharapkan dapat juga meningkatkan efek dari dakwah terhadapa masayrakat luas.Pemilihan dakwah secara digital membuat da'i menyesuaikan ceramah dengan isu yang sedang hangat dikalanganmasyarakat, sehingga mampu menjawab persoalan hidup manusia.

Fenomena dakwah siber berimbas juga pada trend hijrah.Hijrah menjadi hal yang viral belakangan ini dikalangan millennial.Kata hijrah dianggap sebagai kesuksesan dalam mencapai sebuah tujuan hidup. Hijrah pada millennial dapat dilihat dari identitas seperti hijab, cadar, khimar, pakaian yang longgar dan gaya hidup sesuai syariat lainnya. Sejatinya, hijrah bukan hanya mengubah cara penampilan saja tetapi perubahan aspek perilau secara menyeluruh. Yang semula tidak baik menjadi lebih baik.Qadariah dalam Haris ${ }^{5}$ menyebutkan bahwa penelitian yang dilakukan pada anggota komunitas pemuda hijrah mendapatkan hasil bahwa diantara anggota masih ada yang bersifat pamer (riya') atau mencitrakan diri sebagai orang yang religius. Pembawaan diri sebagai umat religi akan memudahkan diterima di lingkungan sekitar.

Pesan dakwah yang menyasar pada generasi millennial jika disampaikan kurang tepat dalam tradisi dakwah lisan ${ }^{6}$. Pengemasan dakwah secara komplek mulai dari gambar, audio visual dan kata-kata yang bagus akan sangat memerlukan dukungan perkembangan teknologi dan media untuk kegiatan berdakwah. Metode pun diubah jika sebelumnya dilakukan dengan cara konvensional, kini harus

${ }^{4}$ Rio Febriannur Rachman, Perspektif Karen Armstrong Tentang Islamofobia Di Media Barat, Dakwatuna: Jurnal Dakwah Dan Komunikasi Islam, 4.2 (2018), 282-91.

${ }^{5}$ riri Nugraha Haris, 'Motivasi Hijrah Milenial Muslim Perkotaan Melalui Dakwah Digital, Muharrik, 3.02 (2020), 175-94 < https://doi.org/10.37680/muharrik.v3i02.398>.

${ }^{6}$ Adi Wibowo, 'Penggunaan Media Sosial Sebagai Trend Media Dakwah Pendidikan Islam Di Era Digital, 03.02 (2019), 339-56. 
diorientasikan secara digital melalui media sosial 7. Adanya internet membuka peluang dakwah semakin besar. Mubalig akan berperan petingn dalam membina pribadi masyarakat sesuai dengan ajaran islam.

Era disrupsi digital menjadi angin segar dalam perkembangan dakwah di Indoensia. Para da'i atau mubaligh dapat memanfaatkan berbagai platform digital untuk menyampaikan dakwahnya. Pesan yang disampaiakna pun dibuat semenarik mungkin dengan tidak meninggalkan ajaran islam itu sendiri. Selain itu gaya komunikasi dan retorika juga diolah mubaligh akan mendapatkan pemirsa yang banyak. Dalam dakwah ada ajakan taubat agar mengubah situasi menjadi ideal sesuai tuntunan agama. Paling tidak sekarang tantangan dakwah islam bersentuan dengan arus globalisasi dan pluralislme agama ${ }^{8}$.

Bahkan untuk beberapa mubaligh telah memiliki jargon masing-masing untuk menyapa khalayaknya.Masyarakat sepertinya tidak hanya butuh ajaran, tapi perlu da'i yang bisa menyelipkan unsur hiburan dan penyampaian yang baik. Pemilihan masyarakat akan tipe da’i dapat dilihat dari jumlah pengikut pada platform masing-masing.

Klasifikasi media sosial ditentukan dari karakteristik penggunanya.Kemudahan menelusuri dakwah di dunia maya menjadi hal positif sedangkan negatifnya sumadi (2016) dalam Wibowo 9 menyebutkan bahwa media dakwah sering digunakan untuk menyampaikan pesan-pesan permusuhan, kekerasan dan pesan negative lainnya.dai akan dihadapkan pad akarakteristik masyarakat yang heterogen dan anonimitas. Dengan tidak pernah mengenal sebelumnya, dan memiliki banyak corak dan latar belakang lainnya. Manakala masyarakat yang masih mememgang teguh tradisi yang telah diwariskan oleh generasi sebelumnya akan berakibat penolakan. Bahkan tidak jarang, mubaligh dihujat oleh masyarakat karena gaya komunikasi yang tidak sesuai dengan karakteristik masyarakat tertentu maupun pesan dakwah yang dianggap intoleransi dan terlalu ortodoks.

Berdasarkan data dari Hootsuite.com, pada 2020 jumlah platform yang paling sering dikunjungi oleh pengguna internet di Indonesia :

Gambar 1 : Pengguna Internet Indonesia 2020

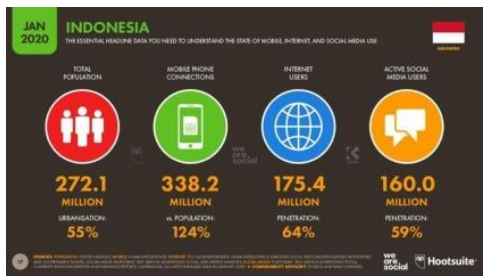

Sumber : Hootsuite ${ }^{10}$

${ }^{7}$ Athik Hidayatul Ummah, M Khairul Khatoni, and M Khairurromadhan, Podcast Sebagai Strategi Dakwah Di Era Digital: Analisis Peluang Dan Tantangan', XII.2 (2020), 210-34.

${ }^{8}$ nur Ahmad, 'Tantangan Dakwah Di Era Teknologi Dan Informasi', At-Tabsyir, I.Juni 2013 (2013), 19-44.

${ }^{9}$ Wibowo.

${ }^{10}$ Hootsuite, Indonesia Digital Report 2020, Global Digital Insights, 2020 $<$ https://datareportal.com/reports/digital-2020-global-digital-overview>. 
Berdasarkan gambar 1 dapat dilihat bahwa setiap tahun jumlah pengguna internet semakin bertambah.Dari keseluruhan jumlah populasi penduduk lebih dari setengah adalah pengguna internet dan media sosial.Bahkan dalam satu tahun jumlahnya bertambah sebesar 12 juta pengguna. Jika kondisi seperti ini terus berlangsung, internet menjadi peluang besar bagi syiar islam. Platform dan situs yang sering dikunjungi oleh pengguna dapat dilihat pada tabel 1 berikut ini.

\section{Tabel 1. Situs yang sering dikunjungi oleh pengguna internet di Indonesia ${ }^{11}$}

\begin{tabular}{llcc}
\hline \multicolumn{1}{c}{ Website } & \multicolumn{1}{c}{ Kategori } & $\begin{array}{c}\text { Kunjungan } \\
\text { Bulanan }\end{array}$ & $\begin{array}{c}\text { Waktu } \\
\text { Kunjungan }\end{array}$ \\
\hline Google.com & Search & 1.689 .000 & $8 \mathrm{M} \mathrm{53S}$ \\
Youtube.com & Streaming Video & 651.300 .000 & $26 \mathrm{M} \mathrm{17S}$ \\
Facebook.com & Social & 664.800 .000 & $8 \mathrm{M} \mathrm{47S}$ \\
Tribunnnews.com & News dan Media & 216.700 .000 & $4 \mathrm{M} \mathrm{24S}$ \\
Detik.com & News dan Media & 156.700 .000 & $5 \mathrm{M} \mathrm{20S}$ \\
Instagram.com & Social & 107.500 .000 & $8 \mathrm{M} \mathrm{04S}$ \\
Whatsapp.com & Social & 105.700 .000 & 2M 08S \\
UCWEB.com & Browser & 102.300 .000 & $1 \mathrm{M} \mathrm{35S}$ \\
& Homepage & & \\
Kompas.com & News dan Media & 98.950 .000 & 4M 51S \\
\hline Twitter.com & Social & $\mathbf{9 0 . 2 6 0 . 0 0 0}$ & $\mathbf{1 1 M ~ 4 5 S}$ \\
\hline
\end{tabular}

Sumber: Hootsuite.

Berdasarkan Tabel 1 di atas dapat dilihat bahwa youtube menjadi situs kedua popular yang sering dikunjungi oleh pengguna media di Indonesia.Kebanyakan pengguna mengakses streaming video.Kemudian disusul oleh Faceebook dan isntagram menduduki peringkat keenam.

Konsumsi pesan dakwah melalui ruang virtual ini mengakinatkan uma memahami hanya aspek luarnya saja.Banyak pesan yang terdistorsi oleh segelintir orang yang memanfaatkan keadaan.Video ceramah da'i di crop, kemudian di edit sedemikian rupa untuk menimbulkan keresahan di kalangan masyarakat. Selain dari eksternal, pesan dakwah juga telah mengalami komodifikasi karena diduga sudha tercemar dengan motif ekonomi para da’i ${ }^{12}$. Bahkan popularitas da'i media online setara selebritis nasional.Da'i di Indonesia juga memiliki akun official pada beberapa platfotm.Jumlah pengikut da'i kondang dapat dilihat pada tabel 2 berikut ini.

Tabel 2. Jumlah Pengikut Da'i Pada Tiga Platform

\begin{tabular}{cccc}
\hline Nama Ustad & Youtube & Isntagram & Facebook \\
\hline Abdullah Gymnastiar & 680.000 & 6.500 .000 & 7.100 \\
Abdul Somad & 1.820 .000 & 4.800 .000 & 2.500 \\
\hline
\end{tabular}

\footnotetext{
${ }^{11}$ Hootsuite.

${ }^{12} \mathrm{AA}$; Masyhuri Nuha, 'Post Dakwah Di Era Cyber Culture', Dakwatuna, 6.Agustus
} 2020 (2020). 


\begin{tabular}{cccc}
\hline Adi Hidayat & 369.000 & 3.000 .000 & 24.000 \\
Hanan Ataki & 1.800 .000 & 8.500 .000 & 62.000 \\
\hline \hline Khalid Basalamah & 1.710 .000 & 2.300 .000 & 231.074 \\
\hline
\end{tabular}

Sumber : Observasi peneliti 2021

Berdasarkan tabel 2 diatas dapat dilihat bahwa jumlah pengikut masingmasing Da'i terbilang banyak.Untuk AA Gym yang hanya memperoleh pengikut sebanyak 680.000 pada platform youtube tapi memiliki Follower tinggi pada instagram.Diantara ustad popular tersebut Khalid Basalamah yang memiliki audiens terbanyak dan merata pada tiap platform.Kominfo pada tahun 2020 juga mencatatkan pengguna internet di Indonesia sebesar 17,5 juta. Jumlah ini meningkat dari tahun 2019 sebesar 25 juta.Jumlah pengguna media sosial mencapai 160juta dan yang menggunakan koneksi internet sebesar 338 juta.Dari banyaknya pengguna mobile menunjukkan bahwa generasi muda menggunakan internet sebagai kebutuhan pokok.Dengan sasaran tersebut, dakwah pun harus beradaptasi dengan kebutuhan target sasaran (mad'u).

Platform youtube menjadi pilihan popular dikalanagan da'i.Selain menampilkan audio visual, tayangan ini dapat dinikmasti secara berulang oleh khalayak. Ada yang bersifat live danada yang delayed. Untuk jamaah yang ketinggalan dan tidak sempat hadir secara virtual dapat menonton ulang setelah siaran langsung berakhir. Mencari perbandingan materi dakwah pun sangat mudah, hanya dengan sekali klik seluruh tampilan ceramah dengan jumlah viewers tertinggi akan muncul padalayar.

Penelitian pemanfaatan youtube pada dai local di aceh pernah dilakukan olehArief ${ }^{13}$. Dari hasil penelitian tersebut didapatkan hasil bahwa peran da'i melalui dakwah youtube menjadi salah satu cara untuk memperbaiki akidah umat ditengah gempuran banyaknya konten sampah dan tidak mendidik. Internet membuka peluang besar untuk meluaskan ajaran amar ma'ruf nahi munkar.Jika tidak mengambil perasn maka justru mengabitkan kerugian pada umat muslin karena Internet tidak mungkin bisa dihindari.

Penelitian serupa pernah juga dilakukan oleh ${ }^{14}$ pada majelis dakwah albahjah cirebon. Dari hasil penelitian didapatkan bahwa media sosial membuat para dai melakukan pemetaan materi dakwah sesuai kalanagan umur. Materi juga ditambahkan hal-hal yang berisfat viral atau trending topik.Media sosial yang dominan dibgunakan adalah facebook, youtube dan twitter.Adanya siber dakwah seperti ini lebih menyasar kaun milenial karena memang pengguna utamanya. Berdasarkan uraian yang telah disampaikan ternyata media internet menjadi pekuang besar dalam penyiaran islam. Untuk itu topik ini sangat menarik dikaji karena dapat menjawab kelebihan media internet dalam penyampaian informasi islam. Selain itu

${ }^{13}$ Arif Ramdan Sulaeman, Anhar Fazri, and Steve Chen, 'Strategi Pemanfaatan Youtube Dalam Bidang Dakwah Oleh Ulama Aceh Pemanfaatan Youtube Sebagai Media Komunikasi Dalam Menyampaikan Materi Bukan Hanya Digunakan Oleb Ustaz-Ustaz', 11.1 (2020).

${ }^{14}$ Zoko Syahputra, 'Strategi Dakwah Berbasis Social Network ( Tinjauan Majelis Dakwah Al-Babjab Cirebon)', 1.1 (2018). 
sebagai muslim, kita juga dituntut untuk mengambil peran berdakwah dalam segala aspek.

\section{Hasil dan Pembahasan}

\section{Era Disrupsi}

Hadirnya Revolusi Industri ke tengah peradaban dunia mengubha bagaimana caa kita bekerja sehingga mau tidak mau kita juga harus ikut serta dalam penguasaan teknologi. Tak ubah seperti produk kecanggihan zaman, teknologi diibaratkan pisau bermata dua.Jika banyaknya kemudahan yang bisa kita dapatkan, teknologi juga memiliki sisi negative dalam kehidupan.Internet misalnya, selain menawarkan percepatan informasi juga memberikan dampak negative terhadap kehidupan sosial seseorang. Semua informasi masuk dalam jalur personal sehingga kurang menumbuhkan rasa haus hubungan sosial ${ }^{15}$

Industri 4.0 atau yang dikenal dengan era disrupsi ditandai dengan terjadinya transformasi di berbagai bidang.Revolusi ini berkat inovasi disruptif yang menghadirkan paradigma baru, yakni perubahan cepat dalam mengubah atau menggeser tatanan yang lama. Sejatinya disrupsi akan menggantikan cara lama menjadi cara baru dengan bantuan teknologi. Dalam aspek penyebaran informasi pun akan menggeser cara berkomunikasi tradisinal menjadi komunikasi digital. Digitalisasi ini juga terjadi di mana-mana, di kelas, pabrik, ruang publik, dan sebagainya.

Sebagai manusia yang berada pada era digital maka kita harus mampu menempatkan diri dengan baik. Dapat memilah bagaimana terpaan informasi yang merajai semua kehidupan sehingga dampak negatif dihindari. Ironinya jika hari ini kita memerlukan data, maka suatu saat kita bisa menjadi objek data.Kejahatan dunia siber mengintai sehingga komodifikasi seringkali dibuat demi meraup keuntungan. Perkembangan dakwah yang disesuaikan dengan kondisi saat ini tentunya akan memberikan nilai plus dan minus tersendiri bagi penyiaran Islam.

\section{Komunikasi Publik}

Kegiatan dakwah pada da'i masuk dalam ranah komunikasi publik.Komunikasi yang tujuannya adalah mengharapkan perubahan perilaku sama dengan hakikat dalam dakwah. Kepiawaian da’i dalam berbicara dan menyusun pesan dakwah mempunyai andil besar dalam keberhasilan proses komunikasi tersebut. Istilah Komunikasi public pda da'i sering dikaitkan dengan retorika.Retorika dalam pandangan Cleanth Broos dan Roberts Penn Warren dalam bukunya Modern Rhetoric, adalah sebuah seni dalam menggunakan bahasa secara efektif.Definisi ini menunjukkan bahwa retorika mempunyai pengertian sempit, yaitu bicara dan pengertian luas, yaitu penggunaan bahasa, bisa lisan bisa juga tulisan.Beberapa orang yang menyamakan komunikasi publik dan retorika karena berkaitan dengan berbicara kepada orang banyak.Tapi

${ }^{15}$ Jefri Marzal, 'Revolusi Industri 4.0, Bagaimana Meresponnya', Humas Universitas Jambi, 2019 $<$ https://www.unja.ac.id/2019/08/19/revolusi-industri-4-0-bagaimana-meresponnya/> [accessed 25 February 2021]. 
fokusnya adalahpenggunaan bahasa sebagai lambing komunikasi dalam menyampaikan apakah itu tatap muka ataupun menggunakan media.

Komunikasi Dakwah menurut Toto Asmara adalah kegiatan sederhana yang mengajak komunikan dapat ikut serta andil dalam harapan, tujuan dan himbauan yang disampaikan oleh komunikastornya.Inti dalam kegiatan ini adalah persamaan, yakni persamaan makna dan persamaan tujuan.Keterkaitan public speaking dengan komunikasi sebenarnya mengharapkan terjadinya perubahan sikap atau tingkah laku orang lain untuk memenuhi harapan sebagaimana pesan disampaikan.

\section{Media baru dalam dakwah}

Wilbur Schraman dalam Kajian komunikasi mendefinisikan media sebagai teknologi informasi yang dapat digunakan dalam pengajaran.Secara spesifik, yang dimaksud dengan media adalah alat-alat fisik yang menjelaskan isi pesan atau pengajaran, seperti buku, film, video, kaset, slide, dan sebagainya.Adapun yang dimaksud dengan media dakwah, adalah alat yang dipergunakan untuk menyampaikan materi dakwah kepada mad'u. Pada zaman modern seperti sekarang ini, seperti televisi, video, kaset rekaman, majalah dan surat kabar.

Dakwah membutuhkan media atau wasilah. Adapun yang dimaksud dengan wasilah dalam dakwah adalah alat yang dipergunakan untuk menyampaikan materi dakwah kepada mad'u melalui media yang ada, dalam hal ini maka da'i harus memilih media yang paling efektif untuk menyampaikan dakwah dan mencapai tujuan dakwah Islam ${ }^{16}$. Media adalah segala sesuatu yang dapat dijadikan sebagai alat perantara untuk mencapai satu tujuan tertentu.Sedangkan dakwah menurut Aizz dalam Suheri ${ }^{17}$ adalah segala sesuatu yang dapat dipergunakan sebagai alat untuk mencapai tujuan dakwah yang telah ditentukan.

Media dakwah terbagi menjadi dua yaitu media massa bukan media massa. Media masa terdiri dari manusia dan benda begitu juga dengan bukan media massa. Detail bukan media massa pada objek manusia berbentuk seminar, rapat dan sebagainya. Sedangkan pada objek benda dapat berupa visual, audio dan audio visual ${ }^{18}$ yakni :

Hamzah Yakub membagi media dakwah kedalam beberapa bentuk

1. Lisan yakni dakwah secara langsung melalui perkataan seperti ceramah, khutbah, pidato, bimbingan, dan lain-lain

2. Tulisan yaitu bentuk tulisan yang dapat berupa novel, majalah, koran, spanduk, dan lainya

${ }^{16}$ Muhammad Munir and wahyu ilaihi, Manajemen Dakwah Cetakan I Jakarta:Kencana, 2006), h. 32. 16 ' (Jakarta: Kencana, 2006).

${ }^{17}$ Suberi, 'Peran Komunikasi Publik Dalam Menyampaikan Dakwah Islam', Jurnal Network Media, 01.2 (2016), 7-25.

${ }^{18}$ Munir and ilaihi. 
3. Lukisan yakni segala bentuk gambar dapat berupa lukisan, photografi, karikatur dan sebagainya.

4. Audio visual yakni dakwah berupa suara dan gambar. Seperti televisi, internet, dan lain-lainya.

5. Akhlak yaitu sikap atau perbuatan yang mencerminkan ajaran Islam yang dapat dlihat atau ditiru langsung oleh mad'u.

Banyaknya yang ada maka da'i harus dapat memilih media paling efektif untuk mencapai tujuan dakwah.Tentunya dengan pemilihan yang tepat atau dengan menetapkan prinsip-prinsip pemilihan media.Apalagi generasi muda sangat menggandrungi konten kreatif sehingga sesuatu informasi harus trending dulu baru memunculkan minat menyaksikan konten.

Beberapa hal yang perlu diperhatikan pada waktu memilih media adalah sebagai berikut:

1. Tidak ada satu media pun yang paling baik untuk keseluruhan masalah atau tujuan dakwah.

2. Media yang dipilih sesuai dengan tujuan dakwah yang hendak dicapai

3. Media yang dipilih sesuai dengan kemampuan sasaran dakwahnya

4. Media yang dipilih sesuai dengan materi dakwahnya

5. Pemilihan media hendaknya dilakukan dengan cara objektif, artinya pemilihan media bukan atas dasar kesukaan da'i

6. Kesempatan dan ketersediaan media perlu mendapat perhatian

7. Efektivitas dan efensiensi harus diperhatikan

Komunikasi dakwah melalui dunia virtual menjadi strategi yangmenarik karena memiliki keuntungan diantaranya :

a. Pesan akan lebih cepat sampai kepada objek dakwah

b. Mad'u bersifat heterogen dan tidak saling mengenal sehingga masuk dalam setiap lini umur

c. Pesan dakwah dapat diulang ${ }^{19}$ berikut ${ }^{20}$

Secara lebih rinci, manfaat teknologi untuk dakwah adalah sebagai

1. Sebagai media dakwah yang cepat (dalam hitungan detik) dan murah

2. Memudahkan mencari rujukan ayat dan/atau hadits berdasarkan kata atau topik

3. Mencari informasi tentang materi dakwah melalui search engine atau mesin pencari di

4. internet

5. Alat komunikasi yang murah, massal, dan cepat

6. Media dakwah, informasi dan promosi

7. Media membangun citra majelis juru dakwah g. Media untuk meng-counter kesalahan umat

${ }^{19} J u l i s$ Suriani, 'Komunikasi Dakwah Di Era Cyber', An-Nida': Jurnal Pemikiran Islam, 42.2 (2018), 30-51.

${ }^{20}$ Teddy Suratmadji, Dakwah Di Dunia Cyber (Jakarta: Madani Institute, 2010). 
Metode yang digunakan dalam penelitian ini adalah metode kualitatif.Penelitian kualitatif adalah penelitian yang dilakukan pada kondisi objek yang alami, peneliti sebagai instrumen kunci, teknik pengumpulan data dilakukan secara gabungan, data yang dihasilkan bersifat deskriptif, analisis data dilakukan secara induktif, dan penelitian ini lebih menekankan makna daripada generalisasi.Penelitian ini dengan studi etnografi virtual. Studi etnografi virtual merupakan metode etnografi yang dilakukan untuk melihat fenomena sosial dan kultur pengguna di ruang siber. Sebagai sebuah kultur dan artefak kultural, cyberspace atau dunia siber bagi peneliti etnografi virtual bisa mendekati beberapa objek atau fenomena yang ada di internet ${ }^{21}$

Kecanggihan teknologi telah mengubah seseorang untuk mendapatkan wawasan keagamaan. Cukup dengan menggunakan handphone, seseorang akan mendapatkan model pengajian yang diinginkan. Generasi milenial yang akrab dengan teknologi digital telah menjadikan media sosial dan sumber-sumber informasi online sebagai salah satu media pembelajaran, termasuk mempelajari tentang Islam 22

Teknologi harus memunculkan keinginan mubaligh mengubah paradigma dakwah tradisional. Dakwah tidak hanya ceramah, bukan pula hanya mengumpulkan pengajian dengan batasan jumlah pendengar ${ }^{23}$. Jika mubaligh masih mempertahankan ceramah dengan cara lama sedangkan orang-orang sudah banyak beralih kepada produk digital maka tentunya masjid dan majelis akan sepi pengunjung. Apalagi maraknya pengguna media sosial menjadi perhatian sekaligus kecemasan. Bagaimana tidak, informasi sampah berunculan di media siber ${ }^{24}$. Dalam kemasannya media sosial menampilkan dua tampilan yakni realitas dan hiperealitas.Identitas yang anonym dan tumpang tindihnya infromasi menguak budaya media sosial sebagai penimbun sampah.Jika generasi muda semakin jarang ke masjid karean akrab dengan gadget, maka da'i harusmengambil peran untuk menyebarkan syiar islam di dunia cyber. Jangan sampai milenial tergerus dengan genpuran informasi yang mengikis moralitas.

Sebaran dakwah didunia virtual secara massif akan membawa pesan infromasi untuk mengubah hidup menjadi lebih baik sesuai tuntunan islam. Belakangan kita sering mendengar istilah hijrah dilkalangan milenial.. Fakta lapangan menyebutkan bahwa milenial muslim tahu tentang hijrah meskipun tidak semua media sosial dijadikan pintu awal untuk berhijrah. Dari hasil penelitian terbukti bahwasanya melalui dakwah digital mampu meningkatkan

${ }^{21}$ Zainal Abidin Achmad and Rachmah Ida, 'Etnografi Virtual Sebagai Teknik Pengumpulan Data Dan Metode Penelitian', The Journal of Society \& Media, 2.2 (2018), 130 <https://doi.org/10.26740/jsm.v2n2.p130-145>.

${ }^{22}$ Puput Puji Lestari and others, 'Dakwah Digital Dan Generasi Milenial, Tasamuh, 21.1 (2020), 41-58. 51.

${ }^{23}$ Armaidi Tanjung, 'Dakwah Di Cybers Space: Peluang Dan Tantangannya', 2018, 44

${ }^{24}$ lukman Hakim, 'Volume 11 No . 1 Juli 2020 Cyberculture On Social Media: Identity As Trash Of Information Budaya Siber Di Media Sosial: Identitas Sebagai Sampah Informasi, 11.1 (2020), 135-48. 
motivasi hijrah perkotaan dengan capaian $75 \%$ dari penyebaran dakwah melalui media digital 25.Penyebaran dakwah pada generasi milenial dapat dikatakan gampang-gambang susah. Kemudahannya antara lain mahirnya menggunakan perangkat teknologi dan akrab denagnnya. Kesulitannya adalah sering kehilangan identitas sosial karena lebih suka bersembunyi dibalik anonimitas.Anonimitas ini tak ayal sering menjadikan da'i sebagai bulan-bulanan atau sasaran bullyan jika dianggap tidak sesuai dengan pemahannya terhadap ajaran agama.

Seiring kebutuhan zaman, dakwah akan dihadapi pada adaptasi metode yang tidak hanya dilakukan pada satu majelis khusus. Kemudahan sekaligus monetisasi yang didtwarkan media cyber jangan sampai membuat dai terhegemoni sehingga kehilangan esensial sebagai penyeru menuju kebaikan. Belum lagi ulah oknum yang memecah belah umat dengan memotong konten dakwah kemudian membumbui dengan ujaran kebencian. Rendahnya literasi media dan budaya potongkompas mengakibatkan orang tidak jeli membaca berita dan kemudian tanpa sadar ikut menyebarkannya 26

Pesan juga merupakan unsur dalam komunikasi yang tidak bisa diindahkan. Ketepatan dalam mendesain pesan sesuai dengan target khalayak berperan besar dalam keberhasilan pesan. Namun dalam media baru, dikatakan pesan adalah media itu sendiri.Pengemasan pesan dakwah yang up to datedengan wacana kekinianmenjadikan dakwah sebagai sesuatu yang enak dilihat maupun didengar. Namun perlu diingat bahwa pengemasan konsep dakwah tetap mengacu pada syariat islam. Untuk dakwah audio visual misalnya, da'i yang menjadi pembicara dengan khalayak hetergoren harus memperhatikan betul apa yang akan disampaikan agar tidak terjadi hambatan diantara objek dakwah ${ }^{27}$

Secara umum pesan memilki beberapa komponen yakni makna, bahasa dan bentuk.Sifat dari pesan adalah informatif, persuasif dan koersif. Penyatuan ketiga unsur tersebut dalam sebuah kemasan menjadikan pesan sebagai ajang kerativitas oleh para pembuat konten ${ }^{28}$. Konten berisi pesan dakwah dan populer dikalangan da'i saat ini adalah Youtube.Youtube menghadirkan tayangan audio visual dan digemari generasi muda.Selain jangkauan luas, proses monetisasi yang ditawarkan oleh youtube sangat menjanjinkan.Beragam motivasi pemanfaatan youtube di masyarakat seperti akutualisasi diri, ingin terkenal ataupun orientasi pada uang.Semua orang bisa viral dengan mudah, menjadi selebritis juga tidak mesti masuk dalam production house.Peran jurnalisme warga membuat sesoerang bisa terkenal dalam hitungan jam.

Begitu kuat dampak cyber media yang ditimbulkan sehingga banyak konten religi yang muncul pada beranda youtube.Justru hal ini yang bisa memunculkan celah komodifikasi dalam konten dakwah. Dai popular dengan

\footnotetext{
${ }^{25}$ Haris.

${ }^{26}$ Dita Verolyna, Penguatan Literasi Publik Di Era Keberlimpahan Informasi', inLiterasi Media Baru Dan Perilaku Potong Kompas”” (UNIB PRESS, 2017), pp. 51-62.

${ }^{27}$ Edy Sutrisno, 'Moderasi Dakwah Di Era Digital Dalam Upaya Membangun Peradaban Baru', 1.1 (2020), 56-83.

${ }^{28}$ Sutrisno.
} 
sebutan ustadz seleb ${ }^{29}$. Saat ini banyak sekali ustad popular, tapi dalam penelitian ini hanya mengambil tiga da'i dengan penggemar terbanyak yaitu Khalid Basalamah, Abdul Somad dan Hanan Attaki.Khalid Basalamah memiliki pengikut terbesar pada platform facebook, sedangkan Hanan Attaki memiliki banyak pengikut pada platform isntagram, sedangkan UAS tertinggi pada platform Youtube.

Pada channel youtube Khallid Basalamah telah mengunggah sebanyak 1.756 konten video sejak dibuat. Tampilan playlist dibuat untuk memudahkan pencarian materi dakwah yang ingin didengarkan. Rata-rata video yang telah diunggah satu hari mampu menarik jam tayang sebanyak 4.000 viewers. Selain itu da'i ini juga menggelar rekaman kajian ilmiah secara live nonstop selama 24 jam setiap harinya. Video ceramah juga sudah diletakkan google adsense atau iklan yang muncul sebelum tayangan dimulai. Namun sepertinya ustad Khalid tidak menerima endorse. Isi ceramah juga masih tentang kajian-kajian islami.Materi dakwah disesuaikan dengan request dari penggemar.Sehingga dakwah menjadi interaktif meskipun dalam konteks virtual.

Akun instagram Khalid Basalamah juga telah membuat 2.796 post sejak dibuat. Dengan pengikut sebanyak 2.3 juta follower, da'i ini sudah tergolong influencer makro. Tayangan pada akun instagram berupa potongan ceramah singkat,poster dakwah dan beberapa pengumuman jadwal tayangan. Jika dilihat dari instagram, foto dan poster dakwah lebih dominan daripada ceramah singkat.Ada juga ceramah panjang yang ditampilkan pada IG TV.

Selanjutnya pada halaman resmi facebook, Khalid memiliki pengikut sebanyak 231.074 orang.Isi dakwah juga terdiri dari ceramah virtual dan poster dakwah.Tayangan video ceramah pada halaman facebook ditonton hingga jutaan kali dan dibagikan ratsan kali.Desain poster dakwah pun menarik, eye catching dan sesuai dengan kebutuhan zaman.

Ustad Hanan Attaki memiliki pengikut instagram sebanyak 8,5 juta. Sejak dibuat akun ini sudah membuat 921 postingan.Bahkan ustad Hanan Attaki memiliki akun tik tok.Sebagaimana ada beberapa pendapat ulama yang kurang merekomendasikan akun tik tok, justru Hanan Attaki menebarkan dakwah juga pada platform tiktok.Tayangan ceramah ustad Hanan Attaki sedikit berbeda dari Abdul Somad dan Khalid Basalamah.Jika keduanya masih menampilkan ceramah diatas mimbar maka tampilan tersebut tidak ditemukan pada video hanan Attaki.Video dakwahnya menampilkan tempat-tempat menarik di berbagai belahan dunia, subjek manusia dengan kondisi menyentuh serta dibumbui back sound sendu.Dakwah nya malah hanya menjadi dubing disertai subtitle.Pemilihan kata juga lebih mudah dipahami dan tema ceramah disesuaikan dengan topik yang trending.Dakwahnya duduk pada sofa santai dengan baju kemerja dan kupluk dimunculkan pada channel youtube.

Sedangkan pada akun youtube ustad Abdul Somad, telah mengunggah 1.066 video sejak berdiri.Dakwah yang ditayangkan pada merupakan rekaman

\footnotetext{
${ }^{29}$ Ferdi Arifin, 'Mubalig Youtube Dan Komodifikasi Konten Dakwab', Al-Balagh: Jurnal Dakwah Dan Komunikasi, 4(1) (2019), 91-120 $<$ https://doi.org/https://doi.org/10.22515/balagh.v4i1.1718>.
} 
UAS saat berceramah ditengah majelis.Dari postingan tersebut dapat disimpulkan bahwa UAS memiliki jadwal dakwah offline yang padat. Namun dengan bantuan media internet, meskipun penggemar didaerah lain yang tidak bisa ikut dalam majelis secara langsung dapat hadir secara virtual.

Melalui pengamatan peneliti, Hanan Attaki paling mencerminkan dakwah bagi generasi millennial. Dengan konten ceramah yang kreatif tidak ayal membuat penggemar ustad ini paling banyak pada media instagram.Namun ketiganya, mendesain materi dakwah sesuai dengan masalah atau isu yang hangat ditengah masyarakat.Untuk humor, UAS yang paling banyak menyelipkan kata-kata yang membuat mad'u tertawa. Objek dakwah menyenangi gaya bicara danisi materi da'i sehingga jam tayang selalu lebih diatas ribuan kali.

Permasalahan lain yang muncul dari media sosial adalah ciri khas nya yang hadir dalam jalur personal sehingga media siber menjadi sumber utama masyarakat maya mempelajari islam. Lalu tebit sikap skeptis terhadap media yang terverifikasi, masyarakat lebih meyakini apa yang disampaikan relasi mereka ${ }^{30}$. Keberadaan da'i lama dalam kelompok digital immigrant (usia 35-64) belum terlalu eksis dalam dunia siber. Namun dari digital natif (pendakwah muda) seperti Hanan Ataki dan felix Siauw lebih pandai dalam menmbuat konten dakwah yang aktarktif. Pada ustad Hanan Ataki misalnya, menggunakan kata-kata yang easy listening dan menarik perhatian seperrti Ge'er, Di reject, ReConect dan sebagainya. Menyentuh kaum milenial tentu tidak bisa lagi menggunakan cara dakwah tradisional, dakwah akan dikemas sesuai kebutuhan zaman. Tampilan ustad pun lebih trendy, tidak melulu dengan sarung dan kopiah.Tampilan casual ternyata lebih mudah menarik generasi muda untuk mendengarkan ceramah.Identitas menjadi representasi symbol da’i untuk pembentukan anak muda yang shaleh.

Sebenarnya kewajiban dakwah bukan hanya dititkberatkan kepada da'i saja.Allah berfirman dalam surah Al-Imran 104 yang artinya "dan hendaklah ada diantara kamu segolongan umat yang menyeru kepada kebajikan, menyuruh kepada yang ma'ruf dan mencegah dari yang munkar, merekalah orang-orang yang beruntung". Berdasarkan firman allah tersbut maka sudah tentu setiap muslim diwajibkan untuk menyambaikan dakwah kepada seluruh umat manusia.Dakwah merupkan seruan menuju jalan kebaikan. Keberadaan internet menjadikan semesta terasa semakin sempit, dimana peluang dakwah semakin terbuka lebar namun menjadi tantangan bagi da'i agar tidak terlena dengan kemudahan yang ditawarkan dunia siber ${ }^{31}$

Perkembangan syiar islam bergantung pada usaha mubalig dalam menguasai media yang berkembang sesuai perkembangan zaman. Pembelajaran agama melalui media baru dinilai efektif karena mampu menyatukan jarak dan

${ }^{30}$ Luthfi Ulfa, Da’i Dan Pemanfaatan Instagram: Tantangan Moderasi Dakwah Di Era Digital, Jurnal Komunikasi Islam, 09.2 (2019), 264-90.

${ }^{31}$ Muhammad Yahya, 'Dakwah "Virtual” Masyarakat Bermedia Online', Briliant: Jurnal Riset Dan Konseptual, 4.2 Mei 2019 (2019), 249-59. 
waktu.Dewasa ini pembuatan konten dakwah diwarnai dengan kreatifitas, tidak melulu dengan metode ceramah tapi bisa dengan gambar menarik, audio dengan ilustrai music menyentuh serta video animasi.Dakwah melalui dunia siber menjangkau secara global, ntuk itu diperlukan perumusan pesan dakwah yang baik agar tujuan dakwah dapat tercapai ${ }^{32}$. Saying sekali jika mubaligh tidak ikut dalam euphoria media baru ini. Nilai plus dalam penyebaran nilai-nilai religius agama islam dapat menjangkau semua lapisan masyarakat dan memperkuat dengungan syiar islam di seluruh dunia.

Mahirnya cyberspasce melahirkan kebudayaan baru yang disebut dengan cyberculture menampilkan ekspresi keberagaamaan yang kekinian. Ekspresi agama yang dimaksudkan berupa aktivitas dakwah pada sejumlah model yang dikenali sebagai upaya penguatan idendtitas muslim melalui sejumlah platform di dunia siber yang menjanjikan banyak hal ${ }^{33}$. Kegiatan dakwah harus masuk dan mewarnai kehidupan cyberspace atau dunia maya.Artinya bahwa dunia dakwah harus masuk ke dunia cyber melalui media-media yang ada dan berkembang saat ini. Karena media yang ada baik massa maupun online memiliki peran yang sangat besar dalam mempengaruhi sikap dan perilaku orang/public ${ }^{34}$.Nilai plus dan minus dalam cyber dakwah menjadi tantangan dan peluang tersendiri bagi para da'i dalam menyebarkan pesan kebaikan. Meskipun da'i tidak luput dari sasaran hoax dan ujaran kebencian, namun peluangnya sangat besar bagi penyiaran islam saat ini.

\section{Penutup}

Berdasarkan uraian sebelumnya kita ketahui bahwa tantangan zaman menghadapkan kita pada perubahan cara dalam semua aspek kehidupan. Mulai dari penggunaan teknologi hingga cara mendapatkan informasi saat ini. Informasi menjadi sebuah kebutuhan yang tidak kalah pentingnya.Sama halnya dengan internet yang menjadi kebutuhan pokok pada era digital.

Sebagai umat muslim yang diwajibkan untuk menyampaikan pesan kebaikan atau dakwah, maka kita wajib untuk turut andil dalam menebarkan syiar islam. Mubalig atau da'i yang secara khusus menempuh pendidikan agama juga harus mengubah metode dalam berdakwah. Paradigma keliru tentang dakwah yang identik dengan ceramah di masjid harus perlahan beradaptasi sesuai dengan kebutuhan zaman. Dakwah dapat dilakukan secara virtual, baik lisan, tulisan, foto, poster, maupun tayangan audio visual.

Generasi muda saat ini menjadi sasaran utama da'i dalam berdakwah. Pengguna internet semakin bertambah setiap tahun sehingga hal ini menjadi peluang besar bagi kejayaan islam. Gerusan arus globalisasi dapat memudarkan akhlak penerus ditengah lautan konten sampah.Sudah saatnya da'i mengambil peran untuk menanamkan nilai religi dikalangan anak muda.

${ }^{32}$ Noor Azaian and others, 'Cabaran Dakwah Islam Di Alam Siber', 2017.

${ }^{33}$ Moch Fakhruroji, Dakwah Di Era Media Baru, ed. by Triadi Iqbal Nugraha, I (Bandung: Simbiosa Rekatama Media, 2017).

${ }^{34}$ Stai Luqman, 'Volume VIII Nomor 2 Maret - Agustus 2019', VIII (2019), 95116. 
Nilai plus dari teknologi memudahkan proses penyebaran informasi dalam menembus ruang dan waktu dapat menjadikan islam diterima diberbagai belahan dunia. Jika informasi yang disebarkan proporsional, maka tidak terjadi lagi islamophobia. Namun nilai minus nya pun tidak dapat ditampikkan bahwa da'i akan terjebak dalam komodifikasi konten dakwah karena monetisasi dari platform digital sangatlah menggiurkan.

Ketiga da'i populer yakni Khalid basalamah, Hanan Attaki, dan Abdul Somad menggunakan platform digital seperti Youtube, Instagram dan Facebook yang sangat diminati saat ini.Desain pesan dakwah pun disesuaikan dengan klahayak yang dituju dan dibuat sekreatif mungkin.Meskipun berada di gempuran monetisasi, dakwah yang disampaikan oleh ketiganya tidak ada yang berbau komodifikasi.

\section{Daftar Pustaka}

Achmad, Zainal Abidin, and Rachmah Ida, 'Etnografi Virtual Sebagai Teknik Pengumpulan Data Dan Metode Penelitian', The Journal of Society \& Media, 2.2 (2018), $130<$ https://doi.org/10.26740/jsm.v2n2.p130-145>

Ahmad, Nur, 'Tantangan Dakwah Di Era Teknologi Dan Informasi', At-Tabsyir, I.Juni 2013 (2013),

Arifin, Ferdi, 'Mubalig Youtube Dan Komodifikasi Konten Dakwah', Al-Balagh: Jurnal Dakwah Dan Komunikasi, 4(1) (2019), 91-120 <https://doi.org/https://doi.org/10.22515/balagh.v4i1.1718>

Azaian, Noor, Binti Abdul, Mohd Yusof Abdullah, Mohd Azul, and Mohamad Salleh, 'Cabaran Dakwah Islam Di Alam Siber', 2017

Bakti, Andi Faisal, 'Trendsetter Komunikasi Di Era Digital: Tantangan Dan Peluang Pendidikan Komunikasi Dan Penyiaran Islam', 04 (2014)

Fakhruroji, Moch, Dakwah Di Era Media Baru, ed. by Triadi Iqbal Nugraha, I (Bandung: Simbiosa Rekatama Media, 2017)

Hakim, Lukman, 'Volume 11 No . 1 Juli 2020 Cyberculture On Social Media : Identity As Trash Of Information Budaya Siber Di Media Sosial : Identitas Sebagai Sampah Informasi', 11.1 (2020)

Haris, Riri Nugraha, 'Motivasi Hijrah Milenial Muslim Perkotaan Melalui Dakwah Digital', Mubarrik, $3.02 \quad$ (2020), <https://doi.org/10.37680/muharrik.v3i02.398>

Hootsuite, Indonesia Digital Report 2020, Global Digital Insights, 2020 <https://datareportal.com/reports/digital-2020-global-digital-overview>

Iman, M Sofiatul, 'Praktisi Dakwah ( Resolusi Da' i Dalam Menyikapi Masyarakat Cyber ) Dakwah Merupakan Aktivitas Mengajak Manusia Kepada Jalan Yang Dikehendaki Allah Swt, Karenanya ( Hamba Alllah) Tanpa Adanya Aktivitas Seberapa Banyak Jamaah Yang Hadir Saat Aktivitas D', Media Kita, 2.Juli 2018 (2018)

Lestari, Puput Puji, Universitas Islam, Negeri Sunan, and Kalijaga Yogyakarta, 'Dakwah Digital Dan Generasi Milenial', Tasamuh, 21.1 (2020), 41-58

Luqman, Stai, 'Volume VIII Nomor 2 Maret - Agustus 2019', VIII (2019), 95-116

Marzal, Jefri, 'Revolusi Industri 4.0, Bagaimana Meresponnya', Humas Universitas Jambi, $2019<$ https://www.unja.ac.id/2019/08/19/revolusi-industri-4-0- 
bagaimana-meresponnya/> [accessed 25 February 2021]

Munir, Muhammad, and wahyu ilaihi, Manajemen Dakwah Cetakan I Jakarta:Kencana,

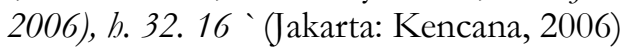

Nuha, AA ; Masyhuri, 'Post Dakwah Di Era Cyber Culture', Dakwatuna, 6.Agustus 2020 (2020)

Rachman, Rio Febriannur, 'Perspektif Karen Armstrong Tentang Islamofobia Di Media Barat', Dakwatuna: Jurnal Dakwah Dan Komunikasi Islam, 4.2 (2018)

Suheri, 'Peran Komunikasi Publik Dalam Menyampaikan Dakwah Islam', Jurnal Network Media, 01.2 (2016), 7-25

Sulaeman, Arif Ramdan, Anhar Fazri, and Steve Chen, 'Strategi Pemanfaatan Youtube Dalam Bidang Dakwah Oleh Ulama Aceh Pemanfaatan Youtube Sebagai Media Komunikasi Dalam Menyampaikan Materi Bukan Hanya Digunakan Oleh Ustaz-Ustaz', 11.1 (2020)

Suratmadji, Teddy, Dakwah Di Dunia Cyber (Jakarta: Madani Institute, 2010)

Suriani, Julis, 'Komunikasi Dakwah Di Era Cyber', An-Nida': Jurnal Pemikiran Islam, 42.2 (2018)

Sutrisno, Edy, 'Moderasi Dakwah Di Era Digital Dalam Upaya Membangun Peradaban Baru', 1.1 (2020), 56-83

Syahputra, Zoko, 'Strategi Dakwah Berbasis Social Network ( Tinjauan Majelis Dakwah Al-Bahjah Cirebon )', 1.1 (2018)

Tanjung, Armaidi, 'Dakwah Di Cybers Space : Peluang Dan Tantangannya', 2018

Ulfa, Luthfi, 'Da' i Dan Pemanfaatan Instagram : Tantangan Moderasi Dakwah Di Era Digital', Jurnal Komunikasi Islam, 09.2 (2019)

Ummah, Athik Hidayatul, M Khairul Khatoni, and M Khairurromadhan, 'Podcast Sebagai Strategi Dakwah Di Era Digital: Analisis Peluang Dan Tantangan', XII.2 (2020)

Verolyna, Dita, 'Penguatan Literasi Publik Di Era Keberlimpahan Informasi', in Literasi Media Baru Dan Perilaku 'Potong Kompas”' (UNIB PRESS, 2017), pp.

Wibowo, Adi, 'Penggunaan Media Sosial Sebagai Trend Media Dakwah Pendidikan Islam Di Era Digital', 03.02 (2019)

Yahya, Muhammad, 'Dakwah “Virtual” Masyarakat Bermedia Online', Briliant: Jurnal Riset Dan Konseptual, 4.2 Mei 2019 (2019) 